\title{
Managing contingencies in requests: The role of negation in Norwegian interrogative directives
}

\author{
Paweł Urbanik ${ }^{\mathrm{a},{ }^{*}, \text { Jan Svennevig }}{ }^{\mathrm{b}}$ \\ a University of Oslo, Department of Linguistics and Scandinavian Studies, Oslo, Norway \\ ${ }^{\mathrm{b}}$ University of Oslo, Center for Multilingualism in Society across the Lifespan, Norway
}

\section{A R T I C L E I N F O}

\section{Article history:}

Received 17 April 2018

Received in revised form 31 August 2018

Accepted 23 October 2018

\section{Keywords:}

Negation

Request

Interrogative

Norwegian

Contingency

Entitlement

\begin{abstract}
A B S T R A C T
In Norwegian, unlike English, negative interrogatives are commonly used as requests for action. In addition, the negation adverb ikke can be placed either before or after a pronominal subject. The study explores pragmatic differences between these two request formats, using everyday conversations from the TV series Big Brother as corpus data. We argue that the difference concerns the contingencies faced by the speaker in gaining compliance. The format with preposed negation (Kan ikke jeg/du X? - 'Can't I/you X?') requests confirmation of the assumption that the interlocutor can and will do the requested action and that any obstacles to gaining compliance are merely hypothetical. The format with postposed negation (Kan jeg/du ikke X? - 'Can I/you not X?'), on the other hand, is used when there are contextually manifest obstacles and the speaker seeks to gain compliance in spite of them. Interrogatives with preposed negation take advantage of premises conducive to having action performed and are used to prevent refusal, while those with postposed negation are employed to combat the obstacles and win compliance.
\end{abstract}

(c) 2018 Elsevier B.V. All rights reserved.

\section{Introduction}

One common way of making requests in Norwegian is to use a modal interrogative of the type Kan jeg/du X? 'Can I/you X?' (Urbanik, 2017). This construction can sometimes be negated. Furthermore, Norwegian language users can position the sentential negation adverb ikke either before an unstressed pronominal subject (Kan ikke jeg/du X? 'Can't I/you X?') or after it (Kan jeg/du ikke X? 'Can I/you not X?'). However, the choice between the two placements is far from random. A close examination of the two negation patterns in informal interaction reveals that the selection of one rather than the other reflects differences in the speakers' assessment of the contingencies faced, especially the interlocutor's willingness or ability to perform the requested action.

The aim of this paper is to investigate the use of both patterns of negation by demonstrating how they reflect and constitute the participants' orientations to the relevant contextual premises. We compare the two types of negative interrogatives with each other and show how their co-occurrence with their positive counterparts and imperative requests in sequences of talk mark dynamic changes in the speakers' assessment of contingencies. Taking a conversation analytic approach, we focus on the relation between the syntactic design of the negated constructions and their sequential relations to previous and subsequent turns at talk. Finally, we propose the semantic explications of the two types of negative interrogative requests in Norwegian.

\footnotetext{
* Corresponding author.

E-mail address: p.k.urbanik@iln.uio.no (P. Urbanik).
} 


\section{Previous research}

\subsection{Interrogative requests}

Since the seminal work of Searle on speech acts (1969), requests, classified by him as directives, have systematically been the subject of enquiry (e.g. Clark and Lucy, 1975; Ervin-Tripp, 1976; Francik and Clark, 1985; Gibbs, 1985; Blum-Kulka et al., 1989). During the past 50 years, studies on the phenomenon of getting others to do something beneficial to the speaker, which is claimed to be among the most basic forms of human communication (Tomasello, 2008), have evolved from mainly philosophical to fine-grained analytical (Drew and Couper-Kuhlen, 2014b).

However, only recently have requesting practices and request formats become of interest in the conversation-analytic research that adopts a more interactional and sequential perspective on language use (e.g. Rossi, 2012; Zinken and Ogiermann, 2013; Drew and Couper-Kuhlen, 2014a; Fox and Heinemann, 2016, 2017). The exceptions were Wootton's studies $(1981,1997)$ on the emergence of various request formats in child development. He has observed that interrogatives carry different interactional properties than other request formats do. Thus, while imperatives mark presumptions that the requested action is in line with the addressee's expectations, the Can you-format appears when there is no sequential evidence that would warrant such presumptions and when the requested action requires departure from the projectable course of activity (Wootton, 1997, 2005). Similar observations have recently been made in studies on everyday interactions among adults and languages other than English: In contrast to imperatives, the use of which was warranted by the parties' previous commitment to an on-going joint project, interrogative formats normally initiated new projects or required the addressees' departure from their own activities (Rossi, 2012; Zinken and Ogiermann, 2013).

Differences between request formats are often described in terms of entitlement and contingency (Lindström, 2005; Heinemann, 2006; Curl and Drew, 2008; Craven and Potter, 2010). Entitlement means "the speaker's grounds for assessing the likelihood of the request being granted and their concomitant display of their right to make the request", while contingency "relates to the recipient's ability or willingness to grant the request" (Craven and Potter, 2010:421). As opposed to imperatives, can-interrogatives are considered to occupy the contingency-side of the scale - as designs which by the fact of giving the possibility of response display uncertainty about compliance and orientation to obstacles that may hinder the granting of request. However, some studies have already nuanced this picture by demonstrating instances from institutional settings in which the use of interrogative formats serves to mark higher entitlement (Heinemann, 2006; Curl and Drew, 2008).

The notion of entitlement can be related to the issue of authority and its epistemic and deontic grounds (Heritage and Raymond, 2005; Stevanovic, 2011; Stevanovic and Peräkylä, 2012). Certain structures enable the requesters to claim knowledge or legitimate power entitling them to expect an action from the requestee.

\subsection{Negation in interrogatives}

The use of negation in polar interrogatives is often described in terms of semantic ambiguity and semantic bias. Bolinger (1957, 1975) has observed that the combination of negation and interrogativity in English leads to two outputs: either to a plain question that does not favor any answer ${ }^{1}$ or to a conducive question that marks 'yes' as an expected answer. This ambiguity is claimed to depend on the scope of negation. Questions such as 'Isn't it raining?' may, depending on the contextual evidence, either check the truth of the negated proposition or seek confirmation of the speaker's positive belief (Ladd, 1981; Büring and Gunlogson, 2000; Romero and Han, 2004; Reese, 2006). In the former case negation concerns the very proposition that is questioned ('It is not raining') in the face of evidence that speaks against this proposition, while in the latter it goes beyond the proposition and concerns the speaker's prior belief and expectation ('I believe that it is raining') on the basis of evidence supporting the proposition (Ladd 1981; Büring and Gunlogson, 2000; Reese, 2006). The latter variant with the outer scope of negation has, therefore, been looked at as an operation of expectedness constraint on negation (Allwood, 1977). Furthermore, it has been noted that its role is to narrow the range of outcome options or challenge the addressee's statements or actions (Heritage, 2002; Krifka, 2017).

The semantic properties of negation have also been investigated with reference to its position in relation to the subject in the English sentence structure. Polarity questions with preposed (or high) negation have been claimed to be biased by default and to generate an implicature about the speaker's expectation of a positive answer, while those with postposed (or low) negation are considered to lack this property (Romero and Han, 2004). ${ }^{2}$ The presence of this bias, as Romero and Han (2004) argue, presupposes some degree of uncertainty resulting from a conflict between the speaker's previous belief about the proposition in question and the premises that challenge this belief, hence the need for the addressee's confirmation. This double check may be oriented either to receiving information why the assumption must be rejected (an addressee-oriented reading that can additionally be modified with negative polarity items) or to receiving information whether the speaker's positive assumption should be doubted (a speaker-oriented reading that can additionally be modified with positive polarity items). A few studies on negation in interaction have confirmed previous findings about the conduciveness of negated polar interrogatives (Heritage, 2002; Koshik, 2002; Heinemann, 2005, 2006). In the context of news interviews, Heritage (2002) shows that such questions presuppose shared facts and serve as an argumentative strategy.

\footnotetext{
${ }^{1}$ Bolinger (1975:529) notes that in this case some language users may position negation after the subject (i.e. Is it not sweet?).

2 But see Hartung (2007) on differences between English and German.
} 
Despite the continuous interest in requests, little attention has been paid to the function of negation in their interrogative formats and the role of such requests in interaction. Negative interrogatives were, however, noted in early studies on requests and characterized in terms of their politeness potential. It has been claimed that negative can-questions in English are ambiguous in terms of politeness and may function as either suggestions or orders (Green, 1975). Clark and Schunk (1980) note that negative can-interrogatives may in some contexts mark the speaker's expectation of a positive answer, while in other settings they may indicate that the negative assumption is operative (cf. Ladd, 1981). As the authors emphasize, in either case the request reveals biased belief about the addressee's intent. Leech maintains that a "negative question implicates an actual negative assumption and a cancelled positive belief" (1983:170) and that these two additional implicatures increase the degree of politeness. However, he also makes a distinction between negative can-interrogatives and negative will-interrogatives, assessing the former as less polite than their positive counterparts (Leech, 2014:155-156; cf. Brown and Levinson, 1987:135). This is, he argues, because negative can-interrogatives (e.g. 'Can't you listen for once?') mark a conflict between the speaker's wants and his/her negative expectations, which often results in annoyance accompanying the request (Leech, 2014:156). Brown and Levinson (1987) consider the use of negation as a negative politeness strategy (the socalled 'interactional pessimism') which consists in not assuming the addressee's ability or willingness to perform an action. However, they also recognize that negative questions may assume acceptance by presupposing knowledge of the addressee's wants, which can be used as a positive politeness strategy.

Several researchers have focused on negative requests in languages other than English. Koike (1994) claims that in Spanish such constructions carry an assumption that the addressee can perform the action. The author mentions two instances of the use of negative requests: when the speaker has reasons to expect acceptance or when the speaker is insistent but in a pleading manner. Negative requests have also been reported to be relatively frequent in Danish and their use has been claimed to be less restricted than in German and English (Faerch and Kasper, 1989; Trosborg, 1995). This has recently been confirmed in a conversation-analytic study by Heinemann (2006) in institutional settings. She has demonstrated that by presupposing that the action can be performed, negative can-interrogatives mark the speaker's entitlement to making request and imply that the action is treated as a routine and thus should already have been performed.

In Norwegian the position of negation is fixed. The sentential negation adverb ikke occurs after the finite verb in main clauses (Han gjør det ikke - 'He does it not'; Du bør ikke gjøre det - 'You should not do it') and usually before the finite verb in embedded clauses (Han sier at du ikke bør gjøre det - 'He says that you not should do it'). In yes/no interrogatives it occupies the position after the finite verb, but it normally appears after an unstressed pronominal subject (Bør du ikke gjøre det? 'Should you not do it?') or before a stressed pronominal and any non-pronominal subject (Bør ikke DU/studentene gjøre det? 'Shouldn't YOU/the students do it?'). Yet, in the former case negation can also fairly often occur before the subject (Østbø Munch, 2013). This has mainly been observed in can-interrogatives functioning as requests (Svanes, 1989; Fretheim, 2015; Urbanik, 2017). Preposed negation is claimed to express positive bias towards the performance of action, while postposed negation is considered as a literal question about the validity of its negative proposition (Fretheim, 2015). The presence of negation in Norwegian interrogatives has so far been described as an intensifying modification (Hollos and Beeman, 1978; Faarlund et al., 1997:586) and associated with informal settings (Svanes, 1989). Despite these few observations nothing is yet known about why Norwegian language users shift between the two patterns of negation when they make requests and how this affects and is affected by the action of requesting itself and the interactional environment.

\section{Data and methods}

The data comprises request sequences drawn from the Big Brother Corpus at the Text Laboratory, University of Oslo, ${ }^{3}$ for the purpose of a cross-linguistic study of requesting patterns in Norwegian and Polish (Urbanik, 2017). The corpus contains transcribed video recordings of the Big Brother reality series from 2001, documenting informal conversations and activities of a group of people during 97 days. The group consists of 6 male and 6 female participants aged between 22 and 36 . The participants do basic housework and carry out various tasks given by the host so as they can earn money for which they can buy food and other goods.

The study is carried out within Interactional Linguistics (Ochs et al., 1996; Selting and Couper-Kuhlen, 2001; Couper-Kuhlen and Selting, 2018), which focuses on linguistic constructions in their sequential environments by drawing on Conversation Analysis and providing the linguistic description of phenomena in question. Requests are defined as utterances aiming at or resulting in: a) getting the addressee to do something beneficial to the speaker or a third person, as in 'Can you X?'; and b) getting the addressee to allow the speaker or a third person to do something beneficial to himself/herself, as in 'Can I X?' (cf. Urbanik, 2017). The collected sequences mainly contain simple requests for action or desistance, such as asking the addressee to fetch an object (e.g. a book), do something for the speaker (e.g. make a cup of tea) or cease an already started action. They include both requests as parts of joint projects (when the participants carry out tasks together and the performance of an action contributes to the progression of the whole activity) and as independent initiatives (e.g. when the addressee is recruited to do something beneficial to the speaker). The identified requests were analysed in their interactional contexts, including the participants' bodily orientations if relevant. Additionally, morphosyntactico-semantic and pragmatic properties of their grammatical structures were coded and scrutinized in order to recognize patterns of grammatical composition and provide quantitative evidence.

\footnotetext{
${ }^{3}$ BigBrother-korpuset, Tekstlaboratoriet ILN, Universitetet i Oslo, http://www.tekstlab.uio.no/nota/bigbrother/.
} 
Out of 614 utterances that were identified as requests 190 (31\%) occurred in interrogative formats most of which were built as ability ('Can you X?') or permission ('Can I/we X?') interrogatives. 66 (35\%) of all the interrogative requests were negated. The majority of the negated requests were can-interrogatives with varying person deixis of the subject (see Table 1).

\section{Table 1}

Absolute frequency distribution of requests, their polarity interrogative subtypes, and their negative interrogative formats (PRON $=$ unstressed pronominal subject, $\mathrm{N}=$ non-pronominal, compound or complex subject).

\begin{tabular}{ll}
\hline All identified requests in the data & 614 \\
Positive interrogatives & 124 \\
Negative interrogatives & 66 \\
Kan ikke PRON (Can't PRON) & 32 \\
Kan PRON ikke (Can PRON not) & 25 \\
Kan ikke N (Can't N) & 5 \\
Er det ikke (Is it not) & 3 \\
Skal dere ikke (Shall you not) & 1 \\
\hline
\end{tabular}

Our analysis concerns, therefore, negation in can-interrogatives with unstressed pronominal subjects, having either firstperson or second-person (singular or plural) deictic perspective. ${ }^{4}$ As shown in Table 1, 32 instances of can-requests contain preposed negation, while in 25 instances negation appears after the subject. This distribution corresponds to the pattern reported in Svanes (1989:100), who also found that preposed negation is more common.

\section{Results}

In our analysis we first focus on the general characteristics of the two syntactic patterns of negation in Norwegian caninterrogatives and then we scrutinize each pattern separately, looking more closely at their interactional properties. Finally, we look at the instances in which negative interrogative requests co-occur with their positive counterparts and imperative requests in sequences of talk.

\subsection{Two types of negation in interrogative requests: general characteristics}

The data show that the choice between the two patterns of negation in Norwegian interrogative requests is a matter of different epistemic or deontic grounds affecting the speaker's expectations of the addressee's compliance. This will be illustrated by an analysis of Extract 1, which demonstrates the use of both types of negation in one sequence. Anette stands in front of the kitchen bench and makes breakfast for herself, buttering slices of bread on the cutting board. Lars approaches her and while she goes aside for a while in order to fetch some paper, he takes her place, moves the slices away, and starts cutting bread. Anette waits a bit, looking at the cutting desk, and then asks Lars to let her finish (line 01).

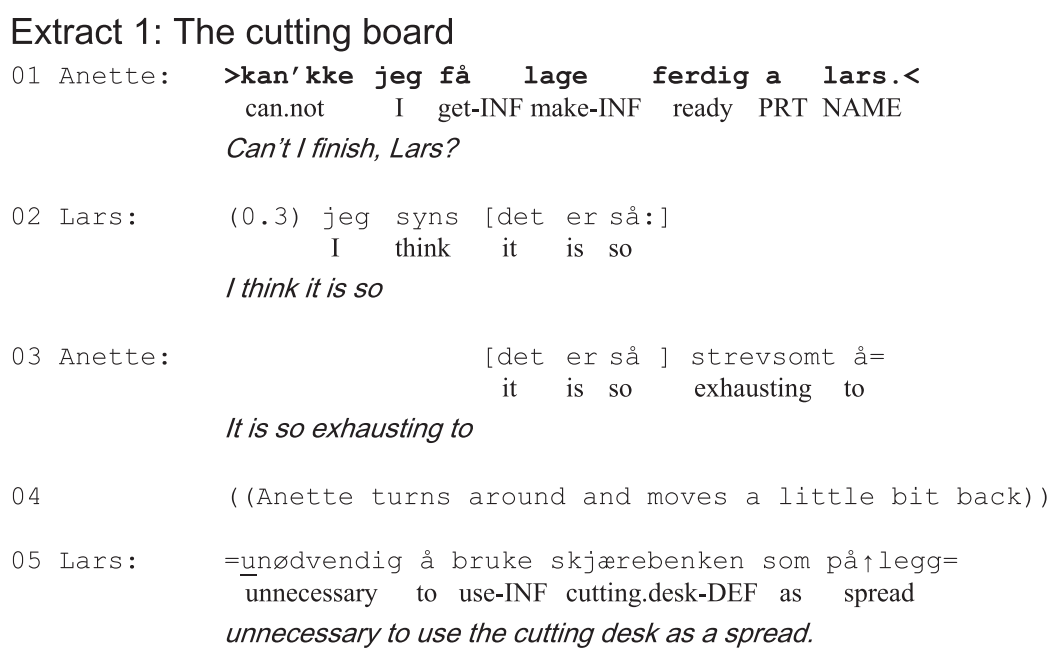

\footnotetext{
${ }^{4}$ Due to the low frequency of formats other than can-interrogatives we decided to exclude the 3 occurrences of Er det $i k k e$ X? ('Isn't it X?') and 1 occurrence of Skal dere ikke X? ('Shall you not X?') from the analysis and merely focus on can-interrogatives. However, in this case we additionally needed to exclude another 5 instances with a non-pronominal, compound or complex subject. Since negation in Norwegian normally precedes "heavy" nominal as well as focused pronominal subjects (Faarlund et al., 1997:880; Østbø Munch, 2013:60-64), this automatically precludes the possibility of manipulating the position of the sentential negation adverb ikke.
} 


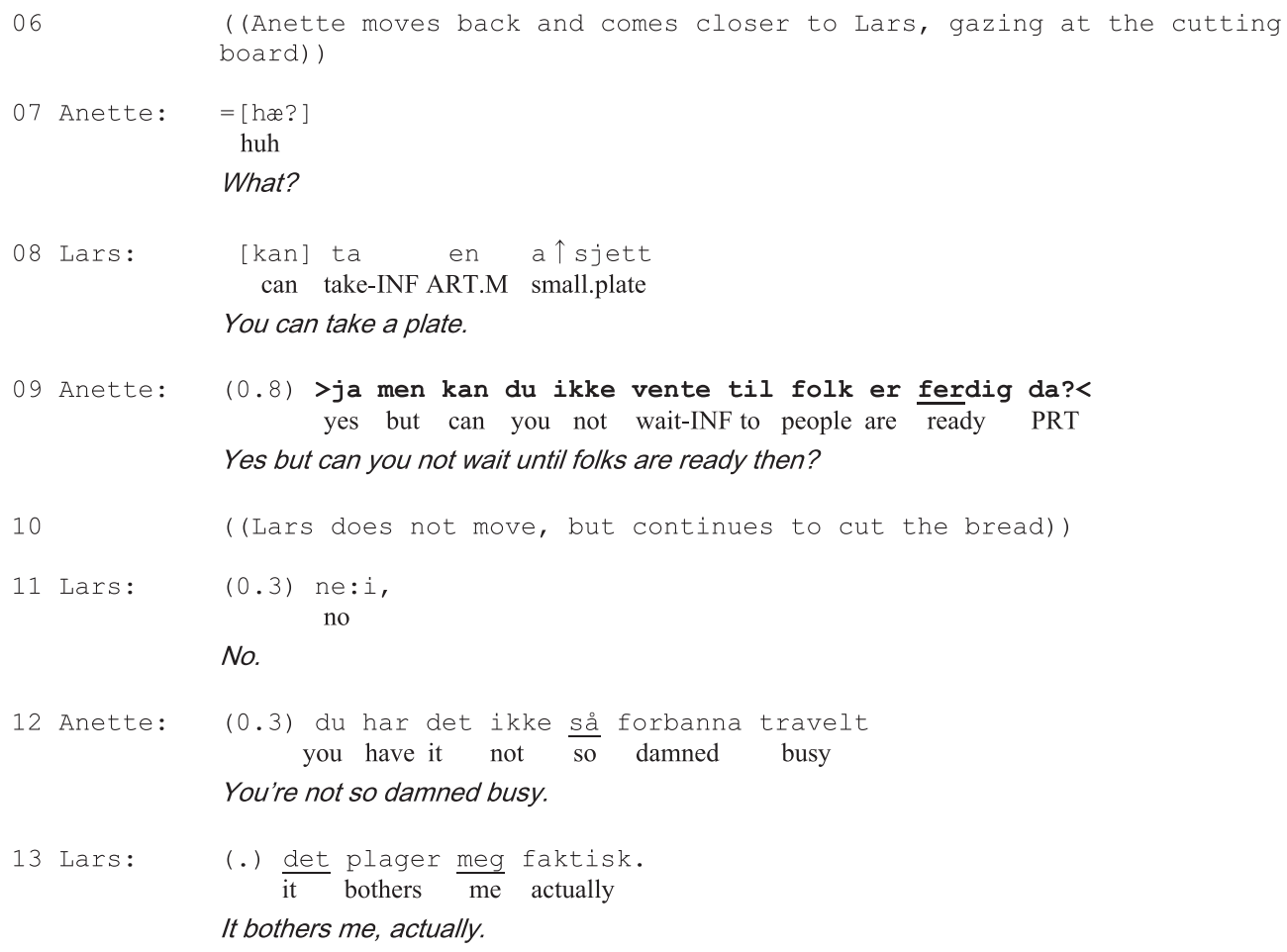

Anette initiates the whole sequence with a can-interrogative with preposed negation. The negation ikke is cliticized and pronounced in the contracted form kan'kke ('can't'), which has been described as a conventionalized way of building requests with positive bias in Norwegian (Fretheim, 2015:275). Additionally, she finalizes her turn with the upgrading particle $d a$ (in the reduced form ' $a$ ) and an address term, both contributing to strengthening the deontic force of the request. Overlapping with Lars' response in line 02 , she initiates a negative assessment that is aborted mid-course, but seems to present the negative consequences for her of Lars' taking her place at the cutting board. This may be considered an account bolstering the request by enhancing her entitlement to make it.

Lars implicitly rejects her request by providing a negative subject-side assessment (Edwards and Potter, 2017) of her actions (using the cutting board to spread the bread), which is thus hearable as a complaint (Schegloff, 1988:121, 2005). In addition, he counters her request by a suggestion in return to take a dish (line 08 ).

Anette, in turn, rejects Lars's proposal, initiating her turn with the disalignment marker $j a$ men 'yes but' (Steensig and Asmuß, 2005) and countering the proposal by reproducing her original request. This time she formulates it as a can-interrogative with a postposed negation and a second-person pronominal subject. In addition, she upgrades the deontic force by emphatically stressing the word ferdig 'ready' and adding the reinforcing particle $d a$. Furthermore, she refers to 'people' rather than herself, thereby presenting the request as based on a social norm of 'waiting for one's turn'. She thus accounts for the legitimacy of the request and thereby enhances her entitlement.

The two instances are requests for the same thing, namely that Lars should move and let her finish preparing her sandwich. However, the contingencies associated with gaining compliance change dramatically during the course of the conversation. While Anette is uttering her first-time request, she has no reason to doubt that Lars will comply, as she was there first and he interrupted her in her activity. By the time she utters the second request, Lars has complained about her activity and thus questioned the legitimacy of the request. She thus has evidence that there are real obstacles to achieving compliance. She addresses these contingencies by claiming entitlement on the basis of a social norm of waiting for one's turn.

Our claim here is that the difference in the placement of the negation in these two instances reflects and constructs the change in contingencies faced. By formulating her initial request as a can-interrogative with preposed negation, Anette checks whether her positive (optimistic) assumption (that he will let her finish) is valid, treating any contingencies as merely hypothetical. The scope of negation in her request goes beyond the propositional content and refers to the positive assumption 
and the premises on which this assumption is based as necessary preconditions for expecting any doubts to be rejected. Her retry with postposed negation addresses the contingencies faced by Lars's rejection by checking whether her negative (pessimistic) assumption (that he will not let her finish) is valid. Consequently, the scope of negation in this request refers directly to the action indicated in the propositional content and the truth of the negated proposition. Yet, since the utterance functions as a repeated request, the preferred response is the rejection of the negative assumption, which in the case of requests again means compliance (cf. Raymond, 2003; Schegloff, 2007:62, 76-78). In this sequence the negative belief is, however, confirmed and Anette overtly marks the dispreference of this confirmation in the following turns developing into conflict between her and Lars.

In the following sections we focus on each pattern in turn in order to provide detailed characteristics of the two ways of expressing negative interrogative requests in Norwegian.

\subsection{Preposed negation: anticipating compliance with some uncertainty}

By selecting can-interrogatives of the pattern Kan ikke PRON ('Can't PRON'), speakers mark that they have reasons to believe that the indicated action can willingly be performed by their addressees. The sources of these reasons can often be traced in the local context and they consist of premises that are conducive to assuming that the addressee will grant the request. Such interrogatives are used prospectively: they normally introduce a new action to be performed and often initiate a whole request sequence, ${ }^{5}$ as in Extract 1 above. The same goes for the next extract. Here, Lars starts playing table tennis with Rodney in the dining room while Rebekka is standing next to the kitchen sink. She utters her request to Lars right after his service and then starts walking towards him in order to take hold of the paddle.

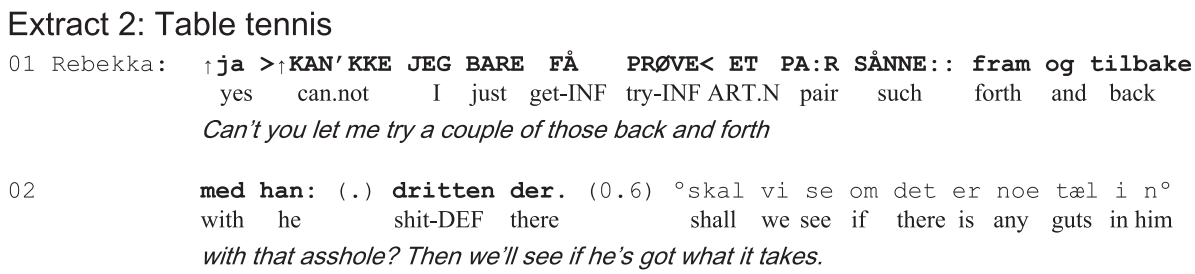

((Lars drops the paddle on the table and Rebekka picks it up))

The situation here is conducive to Rebekka expecting compliance from Lars. Prior to this extract, Ramsy had been teasing her. She is orienting to this activity frame by referring to him with the jocular insult han dritten der ('that asshole'). The activity of 'getting back at Ramsy' is thus invoked to provide for her entitlement to ask for an opportunity to beat him at table tennis. This optimistic projection is furthermore evidenced by her bodily actions. As she is formulating the request, she starts walking toward Lars, thus displaying an expectation that her request will be granted. And indeed, Lars seems to acknowledge her entitlement by merely dropping the paddle on the table for her to take, without responding verbally to the request. All these features converge in indexing this request format as conveying the speaker's entitlement to make the request and expectation of compliance.

Although the request claims entitlement, Rebekka also orients to potential contingencies by reducing the deontic force of the request. She uses the conventionally polite verbal form få prøve ('let me try') and reduces the magnitude of the requested action with the pragmatic particle bare ('just') and the indefinite quantifier et par ('a couple of'). Finally, she adds an account, rationalizing the request by explicating the purpose of it (an 'in-order-to' motive, cf. Schütz, 1953). These features display an orientation to the imposition of the request and the potential contingencies associated with Lars' entitlement to continue playing, given that he has 'the turn' to play (cf. Wootton, 2005; Zinken and Ogiermann, 2013).

This extract is somewhat atypical of the corpus as a whole in that mitigators such as these are highly uncommon with this format (which provides additional evidence of the optimistic projection implied by it). However, accounts are rather frequent: on average, 2 of 5 requests with preposed negation are accounted for. Accounts appear in situations where the speakers acknowledge that the imposition on the addressee might be excessive or that their entitlement to make the request might not be recognized and accepted (cf. Baranova and Dingemanse, 2016 on reasons). The latter case can be observed in Extract 3. Ramsy and Rodney prepare a meal for the group in the kitchen. Rodney stands on the other side of the kitchen island doing his own work, while Ramsy is occupied with checking the meat in the oven. Then, he asks Rodney for assistance with the baking tray in order to be able to toss the pieces of meat.

\footnotetext{
${ }^{5}$ In only three instances can-interrogatives with preposed negation appeared as request retries. In two cases, they echoed requests made by other participants and thus did not constitute real retries in the sense of pursuits of compliance. In the third, the retry occurred after a rejection, and thus constitutes a potential deviant case. This extract is analysed and discussed in detail in Section 4.4 below.
} 


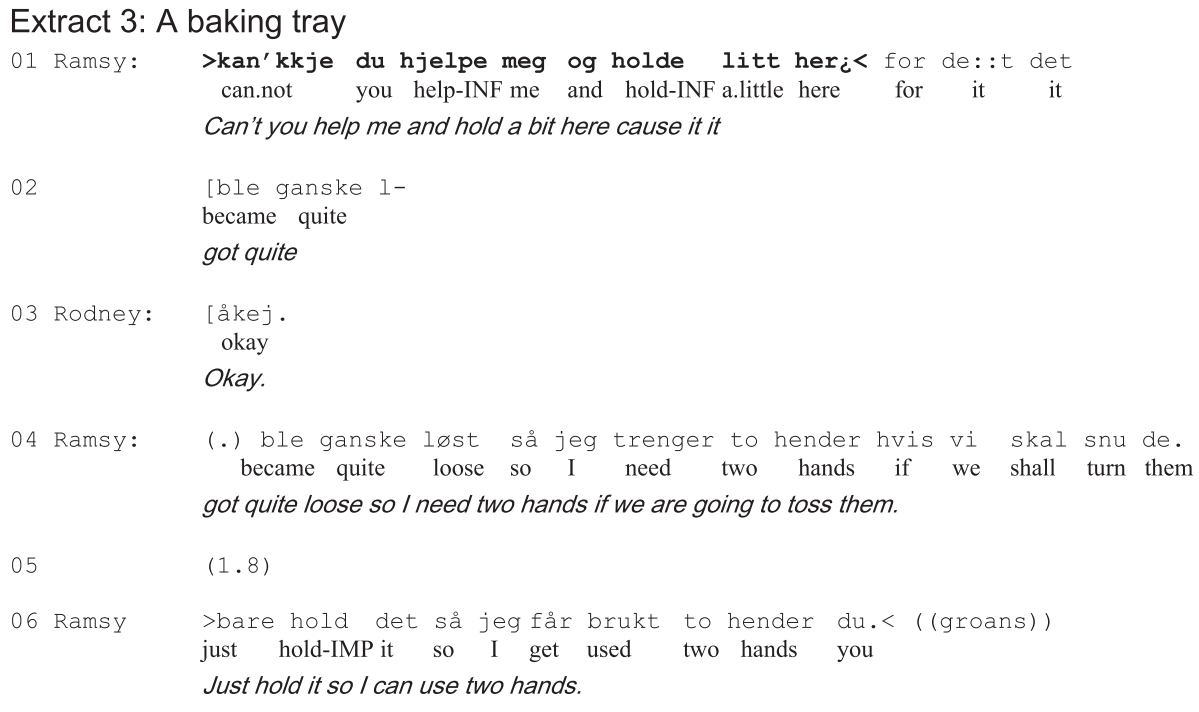

The can-interrogative with preposed negation cliticized to the verb ${ }^{6}$ again marks that Ramsy assumes that Rodney can and will be willing to perform the requested action, although some contingencies cannot be excluded. The action Ramsy asks for is a part of a broader activity he and Rodney are responsible for and collaborate on. Consequently, Ramsy's request for assistance is warranted by the already established joint commitment (Zinken and Rossi, 2016). Yet, Rodney is occupied with his own work, and Ramsy also seems to orient to this by using the verb hjelpe ('help') and the mitigating adverb litt ('a little'). The request is then warranted with an account starting in line 01 and continuing in lines 02 and 04 . The account provides reasons for making the request by explicating both the need for help (the meat being 'loose') and the purpose of the projected action (tossing it). However, Rodney grants the request well before this account is brought to completion.

The design of the request here again strikes a fine balance between entitlement and contingencies. On the one hand, the choice of an interrogative with preposed negation conveys entitlement based on their joint commitment to the collaborative project of preparing a meal. On the other hand, by reducing the magnitude of the favor asked ('a little') and by presenting it as a voluntary act ('help'), based on a pressing need (the 'looseness'), he also recognizes the contingencies associated with Rodney's engagement in competing activities. Importantly, when Rodney accepts the request (line 03) and starts to grant it, the potential obstructions disappear. As a result, while making a retry (line 06), Ramsy uses an imperative format, which explicitly marks that he expects compliance (Craven and Potter, 2010). This construction is typically used in joint projects in Norwegian (Urbanik, 2017) as well as in other languages (Rossi, 2012; Zinken and Ogiermann, 2013; Sorjonen et al., 2017).

In this section we have shown that interrogative can-requests with preposed negation manifest a positive bias in displaying the speakers' expectation of compliance. Thus, they clearly indicate that rejection is not anticipated, which is why they are designed to prevent it. However, interrogativity and additional modulations are employed to display an orientation to potential contingencies as well. In other words, when speakers choose a can-interrogative request with preposed negation, they normally ascribe their addressees willingness to perform the action by implying that a positive response is expected, but they also mark this ascription as somewhat uncertain. Thus, the scope of negation in this format goes beyond the propositional content of the request and concerns the speaker's optimistic beliefs that are expected to be confirmed by the addressee.

The positive bias encoded in this type of negated interrogatives is additionally evidenced by the speakers' bodily orientations. Requests for permission (Kan ikke jeg X? 'Can't I X?') are normally accompanied by bodily actions anticipating a preferred response (as in Extract 2). Furthermore, aspects of the addressees' responses also indicate their orientation to the request format as projecting a positive response. The addressees orient to either the speakers' claim of entitlement by merely complying (as in Extract 2) or to their expression of contingencies by providing a verbal response of commitment (as in Extract 3). However, they hardly ever orient to the uncertainty of compliance implied by the negative propositional content. This can be seen in the form of the response. Norwegian has two different positive polarity tokens: ja, which confirms a positive proposition (as in French oui), and jo, which disconfirms a negatively framed proposition (as in French si). Only in one instance is the latter response token used. In the other instances that are positively responded to, the response tokens are ja ('yes') or åkej ('okay'), revealing speakers' orientation to the action-type preference, not the utterance's polarity (Raymond, 2003). This demonstrates that the participants treat the format as a conventionalized request format projecting compliance rather than a literal question expressing a negative assumption about the addressees' willingness to comply, which again speaks for the outer scope of preposed negation in Norwegian.

\footnotetext{
6 'kkje signifies a dialectal variant of the adverb ikke.
} 


\subsection{Postposed negation: contesting obstacles with some hope}

By selecting a can-interrogative of the pattern Kan PRON ikke ('Can PRON not'), speakers mark their orientation to contingencies already manifest in the local context. Put differently, they have contextual evidence suggesting that the request might be rejected, so it presents itself as a reaction to real obstacles. The contingencies faced are such things as the addressee's manifest resistance in the form of refusal or hesitation (as in Extract 1 above), lack of or delay in the performance of action, or actions that go counter to the speakers' project. Thus, requests of this pattern are used both prospectively and retrospectively: they indicate an action that according to the speaker should have already been performed - either because it has been asked for before but has been rejected or because it has been anticipated in the particular course of an activity but not carried out yet.

We will start with an extract illustrating a request reacting to actions that go counter to the speakers' project. Here, the participants celebrate the Norwegian Constitution Day by organizing an egg-and-spoon race. Two female competitors are waiting for Lars to blow a trumpet as a start signal. However, he teases them by playing the wrong sound (that is not supposed to signal the start) and delays the whole activity.

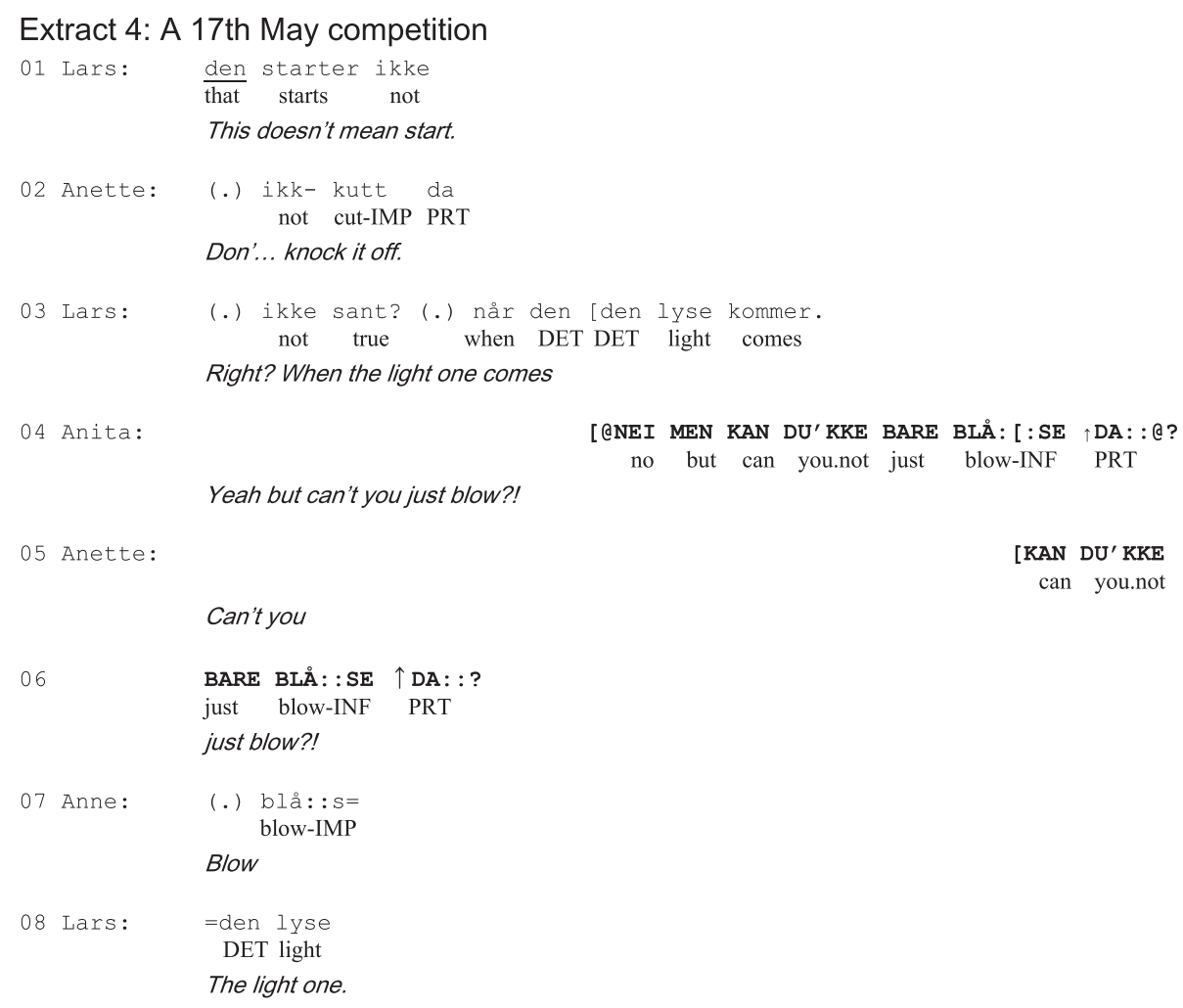

When Lars does not comply with Anette's request to stop teasing them in line 02 and instead continues (line 03), Anita starts shouting out her request in order to rush him (line 04). Her request is prefaced by the disalignment marker nei men ('no but'), upgraded with the pragmatic particle bare ('just') and finalized with the particle da. Her utterance sparks a series of consecutive requests by the other female participants. Anette repeats a similar constructional pattern (lines 05 and 06 ), while Anne chooses an imperative form (line 07), upgrading from a contingent to a categorical expectation of compliance. However, Lars does not respond to either of these requests immediately, but delays compliance by repeating which sound is the right one.

Lars has committed himself to being an arbiter and is expected to fulfill his role by starting the competition. Anita's and Anette's requests occur when he stalls the development of the activity in progress by delaying the expected action. Thus, the obstacle is already established by him and recognized by the two women as real. The participants' common commitment to the activity provides the female participants with the entitlement to expect compliance, and this strong deontic stance is additionally marked by the final particle $d a$ (Urbanik, 2018).

The interrogative with postposed negation addresses the contingencies faced. The request is a literal question in which negation concerns the content of the proposition (inner scope). The speakers check whether it is true that Lars cannot perform the action, thus acknowledging the contingencies and seeking to overcome them. Through this particular syntactic design, Lars is given a way out by being allowed to confirm this negative belief. However, in the context of requesting (rather than asking a question), confirmation is clearly dispreferred. Consequently, the confirmation of the negative belief may require accounting, while denial of the negative belief automatically implies commitment to performing the action and thus constitutes a preferred response. In this way the interrogative with postposed negation constitutes an attempt to gain 
compliance in the face of manifest contingencies. As such, the format contrasts with imperative requests (as the one in line 07) which do not acknowledge the presence of contingencies but instead presuppose immediate compliance.

As a response to resistance, requests of this type express a strong deontic stance of assertiveness and sometimes also impatience. However, by introducing actions that go counter to the interlocutors' expressed plans or intentions, they may also serve to criticize or complain about them. This can be observed in Extract 5 . Here four of the participants check whether a bumblebee they caught has a sting. When Ramsy proposes killing it and Anette suggest waiting until it dies, Lars who sunbathes next to them firmly reacts against their ideas.

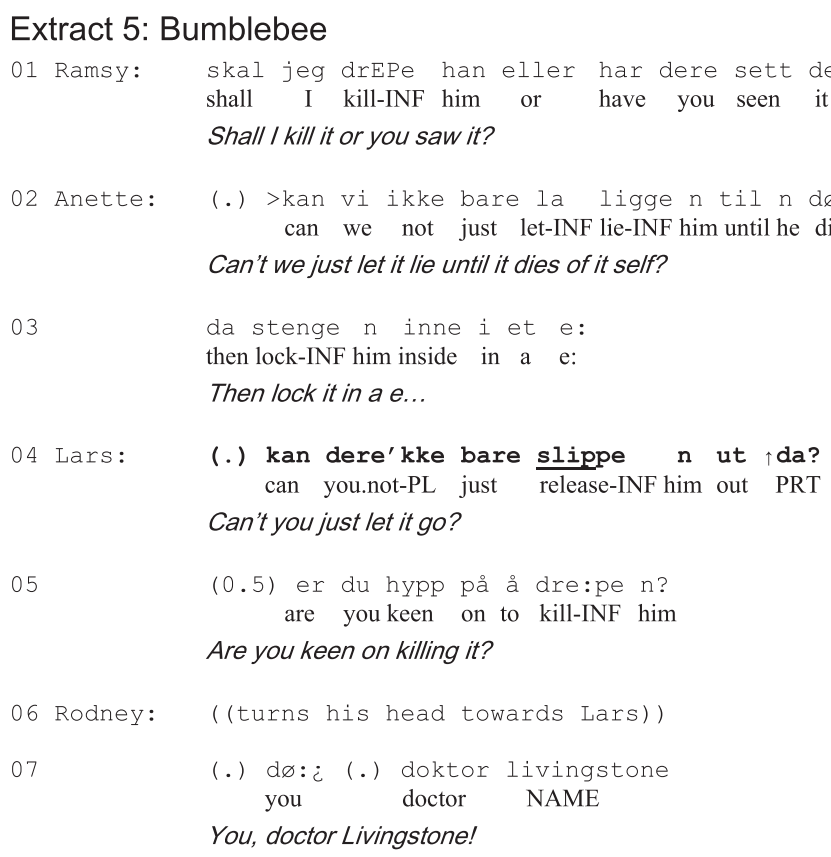

First, in line 02, Anette makes a suggestion with postposed negation, thus presenting it as contrasting with Ramsy's previous proposal. Then in line 04, Lars formulates a counterproposal using the same format. He upgrades the deontic force by adding the pragmatic particle bare ('just') ${ }^{7}$, by stressing the finite verb slippe ('release') and by adding the final particle da. Lars does not take part in the activity, and consequently, the suggestion is oriented towards the out-group, which is marked by the second-person deictic perspective. Furthermore, his response is not produced in the interest of the group, but rather in the interest of the animal. The critical undertone of this suggestion is displayed when, in the face of no uptake, he adds a question (line 05) that rhetorically undermines the legitimacy of Ramsy's proposal by questioning his motivations. The response from Rodney is a reproach, a pronominal vocative with a pejorative character ( $d \emptyset$ - 'you') and a sarcastic characterization of him conveyed by the address term 'doktor Livingstone'.

By formulating his request as an interrogative with postposed negation, Lars opposes the suggestions made by both Anette and Ramsy. Not being a participant in the activity, he does not at the outset have a strong entitlement to decide on their actions. So, the strong deontic stance of his request clearly claims entitlement on different grounds, and his rhetorical question displays that this is the moral value of his position. As such, the negated interrogative with postposed negation does not just orient to an obstacle in terms of contrasting suggestions, but also conveys an implicit criticism of those suggestions.

Requests with postposed negation were almost as often complied with as their counterparts with preposed negation. However, the use of accounts was over half as frequent as in the case of the other pattern. This suggests that accounts mainly serve to warrant the speaker's positive bias regarding compliance. In their responses, the participants again orient to either the entitlement-side (compliance) or the contingency-side (answer) of requests. Yet, they also often mark their orientation to the literal meaning of the question and the presence of negation, either by using the contrastive acceptance token jo or by referring to the literal content of the request in the refusal (see Extract 8 below, line 18).

In this section we have shown that can-interrogatives with postposed negation also mark two conflicting orientations to the likelihood of compliance. Through the position of negation, the speaker manifests a negative semantic bias in this regard. This is because the construction is used as a response to already present and recognized contingencies. In order to check whether the negative belief is true in the face of these obstacles, the speakers ask the addressees to confirm whether it is true that they cannot perform the action (the inner scope of negation). Yet, since the question appears as a reaction to

\footnotetext{
7 The pragmatic particle bare may be either an upgrader or a downgrader, depending on the syntactic position in the utterance and the action it modifies (Opsahl and Svennevig, 2007). In line 02 it is used as a deontic downgrader, reducing the magnitude of the suggested line of action, whereas here it clearly serves to upgrade the deontic strength of the request.
} 
contingencies, it also conveys the speakers' doubts about the truth of the negative belief. The pragmatics of the request situation trumps the semantics of the question and turns denial of the expressed assumption into the preferred response.

\subsection{A deviant case}

As we have seen, the format with preposed negation typically occurs when there are no manifest obstacles to gaining compliance, whereas the format with postposed negation is used to oppose manifest obstacles. However, in one case, we find the format with preposed negation used as a second try after an explicit rejection of the first request. This seems to contradict our analysis and is thus worth examining in more detail. The participants in the Big Brother show have been charged with the task to produce a news bulletin to be radio broadcasted every hour. In the extract below, Monica approaches Morten with a request to join her in reading the news:

\section{Extract 6: Reading the news}

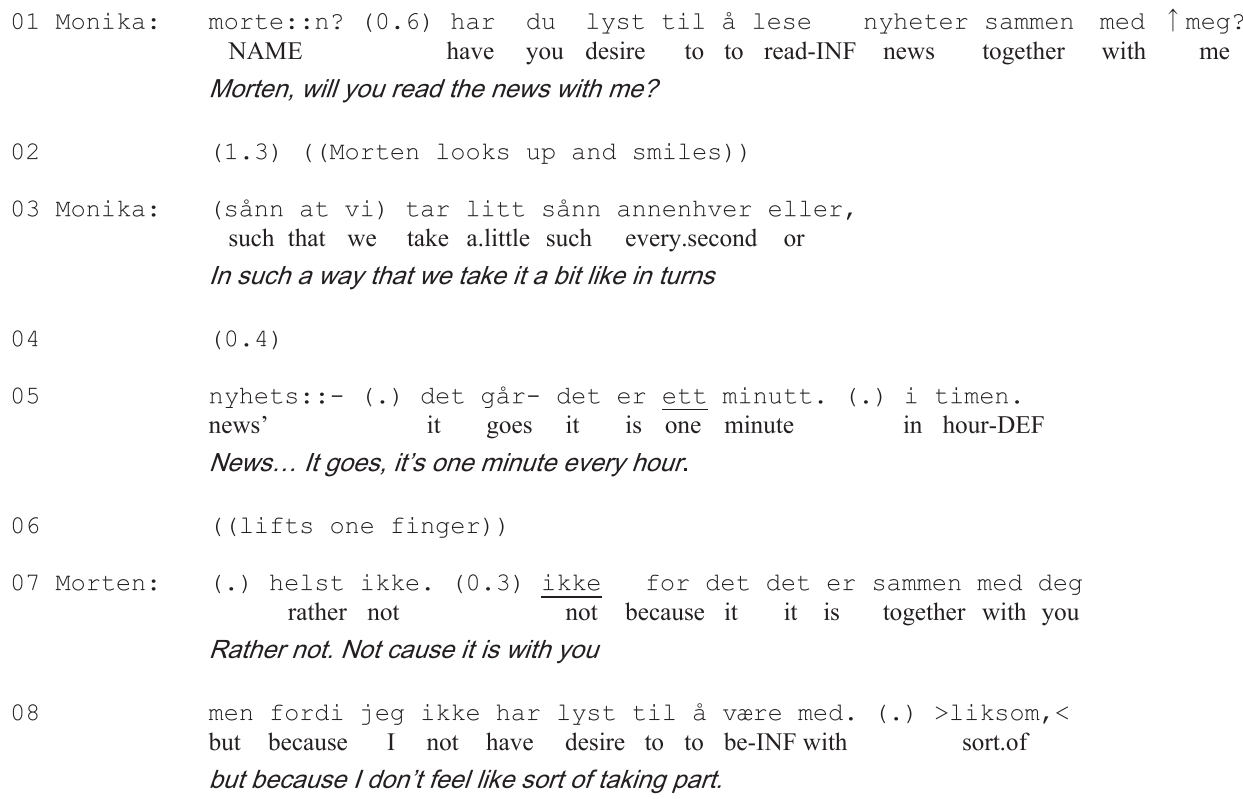

14 Anne:

Can me and you read the news?

Without going into a detailed analysis of the first request, we will just note that it is responded to by a rather direct rejection in line 07 . It is at this point that we find a new request in the form of an interrogative with pre-posed negation.

To explain this apparently deviant case, we will argue that the request is presented as a 'new' or 'first' request rather than a redoing of the previous one. In line 09, Monica changes footing by impersonating a child, thereby switching to a dramatized and 
playful frame (Goffman, 1979). Her voice quality changes significantly as she starts speaking in a higher pitch, a faster pace and with less articulate pronunciation of the words uttered. She also adds the politeness phrase vær så snill ('please'), which in Norwegian is associated with child talk, especially when, as here, it is prolonged, giving it a pleading character. Finally, she tilts her head to the side, a posture which may be associated with pleading (or maybe even with 'cuteness'). This shift in footing thus contributes to establishing the request as a 'first' request in a new, dramatized frame. As such, it does not relate to the previous request sequence but instead sequentially deletes it (Lerner, 1989). This can be seen in the design of the request. First, there is no reference back to the rejection. Normally, redoings after indications of resistance are introduced by some marker of contrast, either the positive polarity items jo or $j a$ ('yes') (as in Extract 8 below) or a contrastive conjunction such as men ('but') (as in Extract 1). Second, there is no reference back to the original request. When requests are redone, they usually take an elliptical and/or pronominalized form, as in Extract 8 (cf. Heritage, 1984 on pro-repeats and Schegloff, 2004 on dispensability). Here, a new full sentence is used, and both the verb (lese - 'read') and the object (nyheter - 'news') are presented in full form without pronominalization and the 'dispensable' prepositional phrase sammen med meg ('together with me') is repeated in full rather than being elided or reduced to just med meg ('with me'). In conclusion, then, several features of the design and delivery of the second request constitute it as an 'as-if first' rather than a 'second' (subsequent) request. The deviant case thus rather confirms than challenges the claim that preposed negation is used when the speaker does not orient to manifest contingencies.

\subsection{Managing shifting contingencies in interaction}

Contingencies are dynamic and change from moment to moment in interaction as the participants display willingness or resistance, ability or inability to perform actions. Thus, requests are frequently formatted differently in subsequent versions of the 'same' request (Rauniomaa, 2017; Etelämäki and Couper-Kuhlen, 2017). In this section we offer two examples that highlight the dynamic changes in the recognition of contingencies in the sequential development of interaction. This allows us to identify crucial differences between negative formats and their positive counterparts as well as imperative requests with regard to how the participants orient to obstacles and claim their rights on a moment-to-moment basis.

Requests with preposed negation differ from positive polarity requests in the degree of entitlement claimed by the speaker. Positive interrogatives are mainly used when the speaker does not have grounds to expect compliance and thus seems to convey a lower degree of entitlement. This can be illustrated in the following excerpt. Anette is standing in front of the mirror doing her make-up. Lars stands by her side and as he moves his head closer to her and to the mirror, he utters the following request:

\section{Extract 7: Bathroom}

01 Lars:

kan du passe deg litt (eller).
can you move-INF you a.little or
Can you move a little?

$$
\begin{aligned}
& \text { jeg må ha: litt plass [ (jeg og). } \\
& \text { I must have-INF little place I too }
\end{aligned}
$$

I need some space, too.

\section{Anette:}

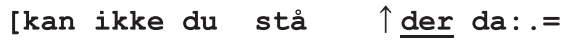

can not you stand-INF there PRT

Can't you stand there.

05 Lars:

((Anette points at a place on the other side of her))

$=\uparrow j o j o$, jegkan stå der.

yes yes I can stand-INF there.

Yeah sure, I can stand there.

06

((Lars starts moving to that place)).

This example reminds somewhat of Extract 1 in that the same participants are asking for more or less the same thing: to have a place where the other person is standing. However, unlike Extract 1, here Anette has the right to the place, given that she was there first. Thus, Lars does not have any a priori entitlement to ask her to move. This is also evident by the fact that he adds an account, providing reasons for granting the request (namely that it is reasonable that he should also have some space by the mirror). In Extract 1, Anette had a claim to the place by the fact that she had been standing at the cutting board first. Thus, the two examples seem to differ mainly in the speakers' entitlement to make the request. The request can also be contrasted with Anette's counterrequest (line 03). Here, she uses an interrogative with preposed negation, claiming entitlement to ask him to move instead. The request claims high entitlement and an expectation of compliance. The positive interrogative thus seems to claim less entitlement.

Requests with postposed negation differ from positive interrogatives mainly in the degree of contingencies faced. Both formats orient to contingencies, but whereas the negated form orients to manifest obstacles to compliance and seeks to overcome them, the 
positive variantseems to express an agnostic attitude to the potential presence of obstacles. We can observethis contrast in the following example. Ramsy has picked up Anne's hair tie from the floor and given it to her, but she asks him whether he can put it in her hair.

\section{Extract 8: A hair tie}

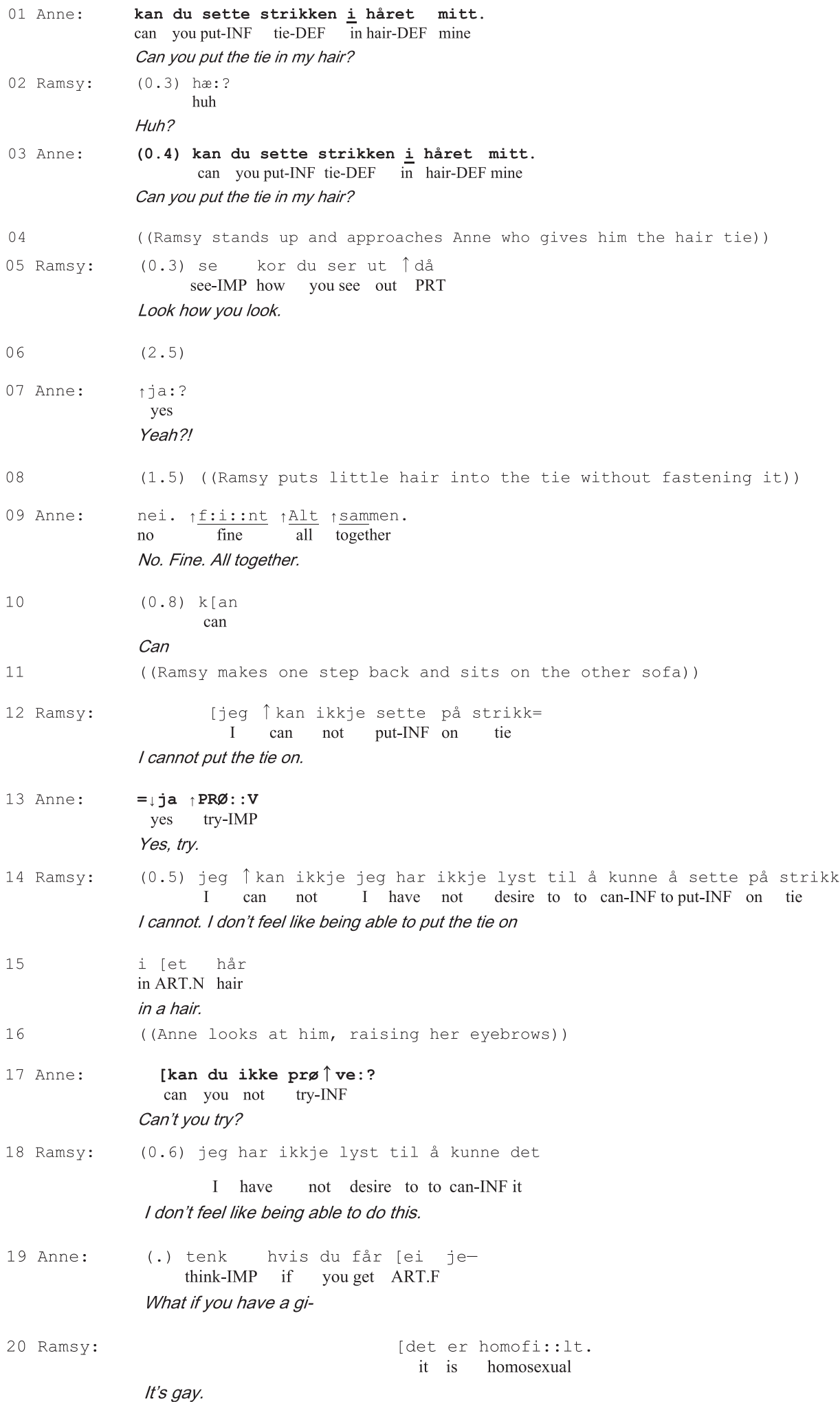


The request with a positive interrogative (line 01) does not claim entitlement to make the request (it is clearly a favor she asks of him) and orients to potential contingencies by expressing it in the question form. At this point, she has no contextual evidence as to what such contingencies might be. However, when she makes a new request in line 17, with a postposed negation, the contingencies have become clear: Ramsy has not done what he was asked to properly, and, even more relevant, he claims not to know how to put hair in a hair tie, neither does he want to learn it. So, whereas the positive interrogative request only acknowledges the potential existence of contingencies, the request with postposed negation orients to manifest contingencies and seeks to overcome them. It thus expresses a stronger deontic stance in that it pursues compliance in the face of real obstacles.

This example also allows us to observe the contrast with imperative requests. When Anne utters the imperative request in line 13 (PRØV - 'try'), she expresses high entitlement and slight consideration for contingencies. Prior to this, Ramsy has accepted her initial request by initiating the non-verbal action of putting her hair in the tie. Her rejection of his attempt (nei'no'), accompanied by admonishments to do it 'nicely' ( $f::: n t$ ) by putting in 'everything' (alt sammen), expresses the normative stance that he has failed to fulfill properly the action that he had committed to (thus, that he is 'at fault'). The imperative request to 'try' thus occurs in a situation where she is clearly entitled to make it. Furthermore, it does not address his previous account, that he does not know how to do it. Accordingly, she does not orient to the contingencies related to his ability, but instead his willingness to try. However, when the request is reinitiated with a negative interrogative in line 17, Ramsy has stated that he does not want to acquire this ability, thus presenting a real obstacle to her request. Her entitlement to make the request has not been altered, but the contingencies have increased considerably.

A similar pattern was observed in Extract 4 above. When requests with negative interrogatives (to blow the trumpet) did not succeed in gaining compliance, the request was changed to an imperative format, thereby dismissing the relevance of the contingencies and upgrading the deontic stance. Consequently, we may conclude that both the imperative and the negative interrogative with postposed negation format claim high entitlement, but contrast in that the negative interrogative orients to manifest contingencies in a way that imperatives do not.

\section{Discussion}

Our study confirms previous claims that negation makes interrogatives semantically biased (see 2.2), but the analysis goes one step further. It shows that this bias results from speakers' ad hoc assessments of the interactionally relevant aspects of the local context. In the case of Norwegian interrogative requests these assessments concern the ontological status of contingencies. Depending on whether contingencies are recognized as hypothetical or real, speakers entertain different assumptions about the likelihood of compliance. Negation serves to mark these assumptions, which may make the utterance pragmatically ambiguous (cf. Clark and Schunk, 1980; Koike, 1994). Yet, in Norwegian the problem of ambiguity is regularly solved through the positioning of negation in relation to the unstressed pronominal subject. ${ }^{8}$

By selecting can-requests with preposed negation, the speaker normally displays the assumption that the addressee will grant the request and that any obstacles are merely hypothetical. However, apart from carrying positive (optimistic) belief about the addressee's reaction, the speaker also checks whether this belief is valid by asking for any reasons to doubt it. In this sense negation remains external in relation to the propositional content and the interrogative is conducive to a positive response (cf. Ladd, 1981; Büring and Gunlogson, 2000), but through the syntactic design it also conventionally marks a dose of uncertainty in this matter (cf. Romero and Han, 2004).

Can-interrogatives with postposed negation occur when speakers orient to already established and recognized obstacles, which is why they reveal rather negative (pessimistic) beliefs about the addressee's compliance. As a result, they literally question the addressee's ability to perform the indicated action in order to double-check whether this negative belief is valid and hopefully receive its rejection. Consequently, the scope of negation remains internal in relation to the propositional content (cf. Ladd, 1981; Büring and Gunlogson, 2000), which is sometimes evidenced by the addressee's orientation to the literal meaning of the request in his/her response.

The use of the two patterns of negation reveals differently shaped contextual conditions that lie at the heart of the syntactic composition of negative interrogative requests. The selection of constructions with preposed negation is prompted by and takes advantage of the premises that are conducive to expecting compliance, including entitlement to make the request and lack of contingencies. The choice of constructions with postposed negation is motivated by and responds to the premises that hinder compliance. As a result, the ultimate aim of the request pattern Kan ikke PRON ('Can't PRON') is to get the positive belief confirmed and any conceivable doubts rejected, hence to prevent refusal. The ultimate aim with the pattern Kan PRON $i k k e$ ('Can PRON not') is, in turn, to get the negative belief rejected and the primary expectations confirmed, hence to win compliance. Thus, the varying position of negation in relation to the subject in interrogative can-requests not only displays syntactic and semantic variation, but reveals different pragmatic properties.

The two patterns also display different interactional characteristics. Interrogatives with preposed negation typically (re) initiate a new action or a new sequence, while their counterparts with postposed negation often occur as subsequent requests (retries). This difference is further evidenced by the fact that disalignment markers, such as men ('but'), ja men ('yes but'), nei

\footnotetext{
${ }^{8}$ Interestingly, when the subject in Norwegian is non-pronominal or pronominal but stressed, the role of negation is rather vague (cf. Romero and Han, 2004:655) and must be disambiguated by the addressee on the basis of additional contextual cues.
} 
men ('no but'), tend to co-occur with requests with postposed negation but not with those with preposed negation. Furthermore, the fact that requests with preposed negation are considerably more often accounted for bears witness to the fact that they often constitute first attempts and thus need rationalization and motivation, whereas requests with postposed

Table 2

Semantic and pragmatic properties of interrogatives with preposed and postposed negation.

\begin{tabular}{|c|c|c|c|}
\hline & & Preposed negation (Kan ikke du X) & Postposed negation (Kan du ikke X) \\
\hline \multirow[t]{3}{*}{ Preconditions } & Contextual premises & Conducive to expecting compliance & Non-conducive to expecting compliance \\
\hline & Orientation & $\begin{array}{l}\text { Contrast between what is anticipated } \\
\text { and what might be obstructive }\end{array}$ & $\begin{array}{l}\text { Contrast between what is (often strongly) } \\
\text { anticipated and what is obstructive }\end{array}$ \\
\hline & Ontology of contingencies & Hypothetical obstacles & Real obstacles \\
\hline \multirow[t]{3}{*}{$\begin{array}{l}\text { Semantic } \\
\text { features }\end{array}$} & Assumption about compliance & $\begin{array}{l}\text { Positive (optimistic) belief }=\text { higher } \\
\text { likelihood of compliance }\end{array}$ & $\begin{array}{l}\text { Negative (pessimistic) belief = lower likelihood } \\
\text { of compliance }\end{array}$ \\
\hline & $\begin{array}{l}\text { Role of negation in the } \\
\text { interrogative }\end{array}$ & $\begin{array}{l}\text { Double check whether there is any } \\
\text { reason to doubt the positive belief }\end{array}$ & Double check whether the negative belief is valid \\
\hline & Scope of negation & External & Internal \\
\hline \multirow{3}{*}{$\begin{array}{l}\text { Pragmatic } \\
\text { features }\end{array}$} & The expected outcome & Confirmation of the positive belief & Rejection of the negative belief \\
\hline & Strategic potential & To prevent refusal & To win compliance \\
\hline & Interactional aim & To prompt compliance & To combat the obstacles \\
\hline \multirow{3}{*}{$\begin{array}{r}\text { Sequential } \\
\text { features }\end{array}$} & Typical sequential position & Initial & Subsequent \\
\hline & Structural orientation & Prospective (initiates a new action) & $\begin{array}{l}\text { Retrospective and prospective (responds to } \\
\text { obstacles as a retry) }\end{array}$ \\
\hline & Need for accounting & Frequent & Infrequent \\
\hline
\end{tabular}

negation occur at a stage in the sequence where the speaker's reasons are already displayed in the local context (cf. Baranova and Dingemanse, 2016). Yet another feature is the participants' bodily orientation that projects positive response in the case of interrogatives with preposed negation, but not in the case of their counterparts with postposed negation. All the main differences between the two patterns are presented in Table 2.

Shifting from what distinguishes the two formats to what unites them, we may observe that both patterns have a strong anchorage in the preceding context. This is often additionally marked by the presence of the final particle $d a$ ('then'), which serves to implicitly justify the request by retrospectively referring to the premises that motivate it and warrant the expectation of compliance (Urbanik, 2018). Importantly, the particle da normally modifies negative requests (but not positive ones) because it is additionally designed to mark a contrast between the warranting premises and any potential or real obstacles (Urbanik, 2018). As a result, the particle indicates why the speaker considers that the requested action can (or should) be performed.

Our analysis also shows how the grammatical design of negative interrogative requests forms a hierarchical architecture in which smaller compositional units modulate larger structures. While interrogativity in general serves to mark orientation to contingencies, the presence of negation in interrogatives indicates a contrast between the participants' reasons. In other words, by negating their requests, language users highlight a conflict between their own expectations based on the contextual premises and some counterevidence (for instance, the already manifested expectations of the addressee). This inner contrastiveness of negated interrogatives matches the use of the final particle $d a$ and differentiates negative interrogatives from their positive counterparts in that the latter do not mark that the speaker has reasons to make biased assumptions. Now, through the position of negation, speakers additionally indicate the ontological status of the recognized contingencies and thus the character of the conflict of reasons. By choosing interrogatives with preposed negation, they emphasize their reasons to expect compliance, but also conventionally mark some dose of uncertainty in this matter, as they take into account that the other part might have different reasons (hypothetical obstacles). Through interrogatives with postposed negation they overtly confront the addressee's reasons with their own (real obstacles). Thus, the positioning of negation allows language users to strike the balance between entitlement and contingencies and, depending on the local circumstances, mark how the latter relate to the former. This contrasts with imperatives that do not mark orientation to contingencies. Consequently, the two

Table 3

Semantic explications of imperative and positive and negative interrogative request formats in Norwegian.

\begin{tabular}{ll}
\hline Request format & Semantic explication \\
\hline Imperative & 1 I assume that you will perform X \\
& 2 I tell you to perform X \\
Positive interrogative & 1 I do not assume and expect that you can and will perform X \\
& 2 I ask you if you can perform X \\
Negative interrogative (preposed & 1 I assume and expect that you can and will perform X \\
negation) & 2 I am not completely certain about that, so I ask you for confirmation that you really can perform X \\
$\begin{array}{l}\text { Negative interrogative (postposed } \\
\text { negation) }\end{array}$ & 1 I expected that you would perform X \\
& 3 I have received information that contradicts my expectations \\
& perform $X$
\end{tabular}


patterns of requesting we have analyzed in this study seem to lie somewhere between the two extremes of the scale of entitlement and contingencies, that is between imperatives that mark high entitlement and low contingencies and positive interrogatives that mark low entitlement but high contingencies (Craven and Potter, 2010). We may thus sum up the differences between the formats by formulating their semantic explications in Table 3.

\section{Conclusions}

The aim of this article was to compare two syntactical patterns of negation in Norwegian interrogative can-requests and identify their pragmatic features. As we have shown, the presence of negation in interrogative can-requests marks that there is or might be a contrast between the speaker's reasons to expect compliance and the hearer's reasons to perform the action. However, through the position of negation in relation to the subject the speaker can additionally display whom this contrast favors and thus how s/he assesses the chances of having the action performed. When choosing interrogatives with preposed negation (Kan ikke jeg/du X? - 'Can't I/you X?'), the speaker normally manifests that s/he assumes higher likelihood of granting the request with just a dose of cautious uncertainty. This is usually because the contextual premises that underlie this assumption are conducive to expecting compliance, as the speaker does not recognize any real contingencies that would hinder it. When using interrogatives with postposed negation (Kan jeg/du ikke X? - 'Can I/you not X?'), the speaker marks that $\mathrm{s} /$ he is already faced with obstacles to granting the request, which is why the assumed likelihood of compliance is lower and the speaker's position is relatively disadvantageous. As a result, in the case of the former pattern the speaker uses negation to prompt compliance and prevent refusal, while in the case of the latter pattern s/he uses negation to combat the obstacles and win compliance.

As our study demonstrates, grammar not only serves to build meaning, but also to nuance it. Grammatical variants within formats performing a certain social action are not only alternative ways of expression, but important modulators (and manipulators) in the meaning-making process. Language users take advantage of alternative grammatical resources in order to mark their orientations to salient contextual features at a given point of interaction, such as contingencies, but also to display variation in how they assess these features and how this affects assumptions they make. In this way grammar is subordinated socio-cognitive needs and is used to display these needs by encoding and pointing to the aspects of the social reality that are most relevant to actions we perform in talk.

\section{Acknowledgements}

We would like to thank Thorstein Fretheim for his valuable observations he shared with one of the authors at the early stage of the study. We are also very grateful for all the comments we received during a seminar at the Department of Linguistics and Scandinavian Studies at the University of Oslo where we presented our results. Last but not least, we thank the two anonymous reviewers for their constructive and helpful comments and suggestions.

\section{Appendices}

\section{Appendix A. Transcription symbols}

[ Beginning of overlapping talk

] End of overlapping talk

$=\quad$ Latched talk

(0.4) Silence in seconds and tenths of a second

(.) A micropause less than 0.2 seconds

Falling intonation

Continuing intonation

Rising intonation

Slightly rising intonation

$\uparrow \downarrow \quad$ Sharp changes in pitch (rise or fall)

$>$ word $<$ Faster talk

wo:::rd Sound stretching

word Stress

wor- A cut-off

${ }^{\circ}$ word ${ }^{\circ}$ Quieter talk

WORD Loud talk

@ “Smile voice"

(word) Transcriber's guess of an unclear fragment

((word)) Transcriber comment 
Appendix B. Glossing abbreviations

$\begin{array}{ll}\text { ART } & \text { article } \\ \text { DEF } & \text { definite } \\ \text { DET } & \text { determiner } \\ \text { F } & \text { feminine } \\ \text { IMP } & \text { imperative } \\ \text { INF } & \text { infinitive } \\ \text { M } & \text { masculine } \\ \text { NAME } & \text { name } \\ \text { NEG } & \text { negation } \\ \text { N } & \text { neuter } \\ \text { PRT } & \text { particle } \\ \text { REFL } & \text { reflexive pronoun } \\ \text { SUP } & \text { supine }\end{array}$

\section{Appendix C. Supplementary data}

Supplementary data to this article can be found online at https://doi.org/10.1016/j.pragma.2018.10.014.

\section{References}

Allwood, Jens, 1977. Negation and the strength of presuppositions: or there is more to speaking than words. In: Dahl, Ö. (Ed.), Logic, Pragmatics and Grammar. University of Gothenburg, Gothenburg, pp. 11-52.

Baranova, Julija, Dingemanse, Mark, 2016. Reasons for requests. Discourse Stud. 18 (6), 641-675. https://doi.org/10.1177/1461445616667154.

Blum-Kulka, Shoshana, House, Juliane, Kasper, Gabrielle (Eds.), 1989. Cross-cultural Pragmatics: Requests and Apologies. Ablex Publishing Corporation, Norwood.

Bolinger, Dwight, 1957. Interrogative Structures of American English. University of Alabama Press, Alabama.

Bolinger, Dwight, 1975. Aspects of Language. Harcourt Brace Jovanovich, New York.

Brown, Penelope, Levinson, Stephen, 1987. Politeness: Some Universals in Language Usage. Cambridge University Press, Cambridge.

Büring, Daniel, Gunlogson, Christine, 2000. Aren't Positive and Negative Polar Questions the Same? Working Paper, UCSC/UCLA. https://urresearch. rochester.edu/institutionalPublicationPublicView.action?institutionalitemId=1347. (Accessed 8 April 2018).

Clark, Herbert, Lucy, Peter, 1975. Understanding what is meant from what is said: a study in conversationally conveyed requests. J. Verb. Learn. Verb. Behav. 14 (1), 56-72. https://doi.org/10.1016/S0022-5371(75)80006-5.

Clark, Herbert, Schunk, Dale, 1980. Polite responses to polite requests. Cognition 8 (2), 111-143. https://doi.org/10.1016/0010-0277(80)90009-8.

Couper-Kuhlen, Elizabeth, Selting, Margret, 2018. Interactional Linguistics: Studying Language in Social Interaction. Cambridge University Press, Cambridge.

Craven, Alexandra, Potter, Jonathan, 2010. Directives: entitlement and contingency in action. Discourse Stud. 12 (4), 419-442. https://doi.org/10.1177/ 1461445610370126.

Curl, Traci, Drew, Paul, 2008. Contingency and action: a comparison of two forms of requesting. Res. Lang. Soc. Interact. 41 (2), 129-153. https://doi.org/10. $1080 / 08351810802028613$.

Drew, Paul, Couper-Kuhlen, Elizabeth (Eds.), 2014a. Requesting in Social Interaction. John Benjamins Publishing Company, Amsterdam/Philadelphia. https:// doi.org/10.1075/slsi.26.

Drew, Paul, Couper-Kuhlen, Elizabeth, 2014b. Requesting - from speech act to recruitment. In: Drew, P., Couper-Kuhlen, E. (Eds.), Requesting in Social Interaction. John Benjamins Publishing Company, Amsterdam/Philadelphia, pp. 1-34. https://doi.org/10.1075/slsi.26.01dre.

Edwards, Derek, Potter, Jonathan, 2017. Some uses of subject-side assessments. Discourse Stud. 19 (5), 497-514. https://doi.org/10.1177/1461445617715171.

Ervin-Tripp, Susan, 1976. Is sybil there? The structure of some American English directives. Lang. Soc. 5 (1), 25-66. https://doi.org/10.1017/ S0047404500006849.

Etelämäki, Marja, Couper-Kuhlen, Elizabeth, 2017. In the face of resistance: a Finnish practice for insisting on imperatively formatted directives. In: Sorjonen, M.-L., Raevaara, L., Couper-Kuhlen, E. (Eds.), Imperative Turns at Talk: the Design of Directives in Action. John Benjamins, Amsterdam/ Philadelphia, pp. 215-240. https://doi.org/10.1075/slsi.30.07ete.

Faarlund, Jan, Lie, Svein, Vannebo, Kjell, 1997. Norsk Referansegrammatikk. Universitetsforlaget, Oslo.

Faerch, Claus, Kasper, Gabrielle, 1989. Internal and external modification in interlanguage request realization. In: Blum-Kulka, S., House, J., Kasper, G. (Eds.), Cross-cultural Pragmatics: Requests and Apologies. Ablex Publishing Corporation, Norwood, pp. 221-247.

Fox, Barbara, Heinemann, Trine, 2016. Rethinking format. An examination of requests. Lang. Soc. 45 (4), 499-531. https://doi.org/10.1017/ S0047404516000385.

Fox, Barbara, Heinemann, Trine, 2017. Issues in action formation. Requests and the problem with x. Open Ling. 3, 31-64. https:/doi.org/10.1515/opli-20170003.

Francik, Ellen, Clark, Herbert, 1985. How to make requests that overcome obstacles to compliance. J. Mem. Lang. 24 (5), 560-568. https://doi.org/10.1016/ 0749-596X(85)90046-4.

Fretheim, Thorstein, 2015. A relevance-theoretic perspective on the Norwegian utterance-final particles da and altså compared to their English counterpart then. In: Hancil, S., Haselow, A., Post, M. (Eds.), Final Particles. De Gruyter Mouton, Berlin/Boston, pp. 249-284.

Gibbs, Raymond, 1985. Situational and conventional requests. In: Forgas, J. (Ed.), Language and Social Situations. Springer-Verlag, New York, pp. 97-110. Goffman, Erving, 1979. Footing. Semiotica 25 (1-2), 1-30. https://doi.org/10.1515/semi.1979.25.1-2.1.

Green, Georgia, 1975. How to get people to do things with words: the whimperative question. In: Cole, P., Morgan, J. (Eds.), Syntax and Semantics 3: Speech Acts. Academic Press, New York, pp. 107-141.

Hartung, Simone, 2007. Forms of negation in polar questions. In: Zeijlstra, H., Soehn, J.-P. (Eds.), Proceedings of the Workshop on Negation and Polarity. University of Tübingen, Tübingen, pp. 71-77. https://publikationen.uni-tuebingen.de/xmlui/bitstream/handle/10900/44023/pdf/negpol07.pdf?sequence $=1$. (Accessed 8 April 2018).

Heinemann, Trine, 2005. Requests and offers: some uses of negative interrogatives. MOVIN Working Papers 3.

Heinemann, Trine, 2006. 'Will you or can't you?': displaying entitlement in interrogative requests. J. Pragmat. 38 (7), 1081-1104. https://doi.org/10.1016/j. pragma.2005.09.013.

Heritage, John, 1984. A change-of-state token and aspects of its sequential placement. In: Heritage, J., Atkinson, J.M. (Eds.), Structures of Social Action: Studies in Conversation Analysis. Cambridge University Press, Cambridge, pp. 299-345. 
Heritage, John, 2002. The limits of questioning: negative interrogatives and hostile question content. J. Pragmat. 34 (10-11), 1427-1446. https://doi.org/10. 1016/S0378-2166(02)00072-3.

Heritage, John, Raymond, Geoffrey, 2005. The terms of agreement: indexing epistemic authority and subordination in talk-in-interaction. Soc. Psychol. Q. 68 (1), 15-38. https://doi.org/10.1177/019027250506800103.

Hollos, Marida, Beeman, William, 1978. The development of directives among Norwegian and Hungarian children: an example of communicative style in culture. Lang. Soc. 7 (3), 345-355.

Koike, Dale, 1994. Negation in Spanish and English suggestions and requests: mitigating effects? J. Pragmat. 21 (5), 513-526. https://doi.org/10.1016/03782166(94)90027-2.

Koshik, Irene, 2002. A conversation analytic study of yes/no questions which convey reversed polarity assertions. J. Pragmat. 34 (12), 1851-1877. https://doi. org/10.1016/S0378-2166(02)00057-7.

Krifka, Manfred, 2017. Negated polarity questions as denegations of assertions. In: Lee, Ch, Kiefer, F., Krifka, M. (Eds.), Contrastiveness in Information Structure, Alternatives and Scalar Implicatures. Springer, Cham, pp. 359-398. https://doi.org/10.1007/978-3-319-10106-4.

Ladd, Robert, 1981. A first look at the semantics and pragmatics of negative questions and tag questions. Proc. Chicago Linguistic Soc. $17,164-171$.

Leech, Geoffrey, 1983. Principles of Pragmatics. Longman, London/New York.

Leech, Geoffrey, 2014. The Pragmatics of Politeness. Oxford University Press, Oxford.

Lerner, Gene, 1989. Notes on overlap management in conversation: the case of delayed completion. West. J. Speech Commun. 53 (2), 167-177. https://doi. $\operatorname{org} / 10.1080 / 10570318909374298$

Lindström, Anna, 2005. Language as social action: a study of how senior citizens request assistance with practical tasks in the Swedish home help service. In: Hakulinen, A., Selting, M. (Eds.), Syntax and Lexis in Conversation: Studies on the Use of Linguistic Resources in Talk-in-interaction. John Benjamins Publishing Company, Amsterdam/Philadelphia, pp. 209-230.

Ochs, Elinor, Schegloff, Emanuel, Thomspon, Sandra (Eds.), 1996. Interaction and Grammar. Cambridge University Press, Cambridge.

Opsahl, Toril, Svennevig, Jan, 2007. Må ha det. Bare må ha det. Bare som pragmatisk partikkel i samtale. Nor. Lingvistisk Tidsskr. 25, 29-56.

Østbø Munch, Christine, 2013. North Germanic Negation: a Microcomparative Perspective. PhD Thesis. University of Tromsø, Tromsø.

Rauniomaa, Mirka, 2017. Assigning roles and responsibilities. Finnish imperatively formatted directive actions in a mobile instructional setting. In: Sorjonen, M.-L., Raevaara, L., Couper-Kuhlen, E. (Eds.), Imperative Turns at Talk: the Design of Directives in Action. John Benjamins, Amsterdam/ Philadelphia, pp. 325-355. https://doi.org/10.1075/slsi.30.11rau.

Raymond, Geoffrey, 2003. Grammar and social organization. Yes/No interrogatives and the structure of responding. Am. Sociol. Rev. 68 (6), 939-967. https://doi.org/10.2307/1519752.

Reese, Brian, 2006. The meaning and use of negative polar interrogatives. In: Bonami, O., Hofherr, P. (Eds.), Empirical Issues in Formal Syntax and Semantics 6: Papers from CSSP 2005, pp. 331-354.

Romero, Maribel, Han, Chung-Hye, 2004. On negative yes/No questions. Ling. Philos. 27 (5), 609-658. https://doi.org/10.1023/B:LING.0000033850.15705.94.

Rossi, Giovanni, 2012. Bilateral and unilateral requests: the use of imperatives and mi X? Interrogatives in Italian. Discourse Process 49 (5), $426-458$. https://doi.org/10.1080/0163853X.2012.684136.

Schegloff, Emanuel, 1988. Goffman and the Analysis of Conversation. Polity Press, Cambridge.

Schegloff, Emanuel, 2004. On dispensability. Res. Lang. Soc. Interact. 37 (2), 95-149. https://doi.org/10.1207/s15327973rlsi3702_2.

Schegloff, Emanuel, 2005. On complainability. Soc. Probl. 52 (4), 449-476. https://doi.org/10.1525/sp.2005.52.4.449.

Schegloff, Emanuel, 2007. Sequence Organization in Interaction: a Primer in Conversation Analysis. Cambridge University Press, Cambridge.

Schütz, Alfred, 1953. Common-sense and scientific interpretation of human action. Philos. Phenomenol. Res. 14 (1), 1-38. https://doi.org/10.2307/2104013.

Searle, John, 1969. Speech Acts: an Essay in the Philosophy of Language. Cambridge University Press, London.

Selting, Margret, Couper-Kuhlen, Elizabeth (Eds.), 2001. Studies in Interactional Linguistics. John Benjamins Publishing Company, Amsterdam/Philadelphia.

Sorjonen, Marja-Lena, Raevaara, Liisa, Couper-Kuhlen, Elizabeth (Eds.), 2017. Imperative Turns at Talk: the Design of Directives in Action. John Benjamins Publishing Company, Amsterdam/Philadelphia. https://doi.org/10.1075/slsi.30.

Steensig, Jakob, Asmuß, Birte, 2005. Notes on disaligning 'yes but' initiated utterances in German and Danish conversations: two construction types for dispreferred responses. In: Hakulinen, A., Selting, M. (Eds.), Syntax and Lexis in Conversation: Studies on the Use of Linguistic Resources in Talk-ininteraction. John Benjamins Publishing Company, Amsterdam/Philadelphia, pp. 349-373. https://doi.org/10.1075/sidag.17.17ste.

Stevanovic, Melisa, 2011. Participants' deontic rights and action formation: the case of declarative requests for action. InLiSt - Interact. Linguist. Struct. 52. http://www.inlist.uni-bayreuth.de/issues/52/index.htm. (Accessed 8 April 2018).

Stevanovic, Melissa, Peräkylä, Anssi, 2012. Deontic authority in interaction: the right to announce, propose, and decide. Res. Lang. Soc. Interact. 45 (3), 297-321. https://doi.org/10.1080/08351813.2012.699260.

Svanes, Bjørg, 1989. En undersøkelse av realisasjonsmønsteret for språkhandlingen "å be noen om å gjøre noe. Maal Og Minne 1-2, $89-107$.

Tomasello, Michael, 2008. Origins of Human Communication. The MIT Press, Cambridge (MA)/London.

Trosborg, Anne, 1995. Interlanguage Pragmatics: Requests, Complaints, and Apologies. Mouton de Gruyter, Berlin/New York.

Urbanik, Paweł, 2017. Requests in Polish and Norwegian Informal Conversation: a Comparative Study of Grammatical and Pragmatic Patterns. PhD Thesis. University of Oslo, Oslo. https://doi.org/10.13140/RG.2.2.22721.45922.

Urbanik, Paweł, 2018. Kan ikke du stå der, da? En sosiokognitiv analyse av finalpartikkelen da i interrogative kan-anmodninger. Norsk Lingvistisk Tidsskrift 32 (2), 77-108.

Wootton, Anthony, 1981. Two request forms of four year olds. J. Pragmat. 5, 511-523. https://doi.org/10.1016/0378-2166(81)90016-3.

Wootton, Anthony, 1997. Interaction and the Development of Mind. Cambridge University Press, Cambridge.

Wootton, Anthony, 2005. Interactional and sequential configurations informing request format selection in children's speech. In: Hakulinen, A., Selting, M. (Eds.), Syntax and Lexis in Conversation: Studies on the Use of Linguistic Resources in Talk-in-interaction. John Benjamins Publishing Company, Amsterdam/Philadelphia, pp. 185-207.

Zinken, Jörg, Ogiermann, Eva, 2013. Responsibility and action: invariants and diversity in requests for objects in British English and polish interaction. Res. Lang. Soc. Interact. 46 (3), 256-276. https://doi.org/10.1080/08351813.2013.810409.

Zinken, Jörg, Rossi, Giovanni, 2016. Assistance and other forms of cooperative engagement. Res. Lang. Soc. Interact. 49 (1), 20-26. https://doi.org/10.1080/ 08351813.2016 .1126439$.

Pawel Urbanik is a Postdoctoral Researcher at MultiLing - Center for Multilingualism in Society across the Lifespan, University of Oslo. He holds a PhD in linguistics from the University of Oslo. In his doctoral dissertation from 2017 he compared the grammatical and pragmatic patterns of requesting in Polish and Norwegian. His academic interests include Interactional Linguistics, neo-Gricean pragmatics, intersection between grammar, semantics and pragmatics, linguistic politeness, and Polish-Norwegian contrastive grammar.

Jan Svennevig is Professor of Language and Communication at MultiLing - Center for Multilingualism in Society across the Lifespan, University of Oslo, Norway. His research deals with workplace interaction, L2 conversations, pragmatic particles and communication in dementia. Recent publications include "What's it called in Norwegian?" Acquiring L2 vocabulary items in the workplace (Journal of Pragmatics 2018) and "Pre-empting understanding problems in L1/L2 conversations: Evidence of effectiveness from simulated emergency calls.” (Applied Linguistics, in press). 